\title{
KSIĘGA RODZAJU 12-50 W QUMRAN: INTERPRETACJA OPOWIADAŃ O PATRIARCHACH W WYBRANYCH TEKSTACH Z PUSTYNI JUDZKIEJ
}

Księga Rodzaju zajmuje niezwykle ważne miejsce wśród zwojów odnalezionych na Pustyni Judzkiej nad Morzem Martwym, ${ }^{1}$ o czym świadczy istnienie znacznej liczby kopii biblijnego tekstu tej księgi oraz utworów inspirowanych jej treścią i będących parafrazą materiału biblijnego. W różnych miejscach Pustyni Judzkiej znaleziono przynajmniej 28 kopii tekstu tej księgi, ${ }^{2}$ a mianowicie w Qumran 23 kopie (1Q1, 2Q1, 4Q1, 4Q2, 4Q3, 4Q4, 4Q5, 4Q6, 4Q7, 4Q8a, 4Q8b, 4Q9, 4Q10, 4Q11, 4Q12, 4Q12a, 4Q158, 4Q364, 4Q365, 4Q483, 4Q576, 6Q1, 8Q1), w Wadi Murabba'at jedną kopię (Mur 1), w Wadi Sdeir też

1 Zob. J.R. D a v i 1 a, Genesis, Book of, w: L.H. S c h i f f m a n, J.C. V a n d e r K a m (red.), Encyclopedia of the Dead Sea Scrolls, t. I, Oxford 2000, s. 299-300; S.W. C r a w for d, Genesis in the Dead Sea Scrolls, w: C.A. Ev a n s, J.N. L o h r, D.L. P e t e r s e n (red.), The Book of Genesis: Composition, Reception, and Interpretation, VTSup 152, Leiden-Boston 2012, s. 353-373; zob. też F.H. C r y e r, Genesis in Qumran, w: F.H. C r y e r, T.L. T h o m p s o n (red.), Qumran between the Old and New Testaments, JSOTSup 290, Copenhagen International Seminar 6, Sheffield 1998, s. 98-112.

2 W Qumran mogło być więcej kopii Księgi Rodzaju, ponieważ wydawca tekstu w serii Discoveries in the Judaean Desert wskazuje, że 4Q8 (=4QGen ${ }^{\mathrm{h}}$ ) może zawierać fragmenty czterech różnych rękopisów, mianowicie 4QGen ${ }^{\mathrm{h} 1}$, 4QGen ${ }^{\text {h2 }}$, 4QGen ${ }^{\text {h-para }}$, 4QGen ${ }^{\text {h-title }}$, zob. J.R. D a v i 1 a, 8. 4QGen $h$, w: E. U 1 r i c h, F.M. Cross, Qumran Cave 4, VII: Genesis to Numbers, DJD 12, Oxford 1994, s. 61-64 (+ pl. XII). 
jedną (Sdeir 1), na Masadzie także jedną kopię (Mas 1) i w miejscu niezidentyfikowanym dwie kopie (X9, X10). ${ }^{3}$

Wiele dokumentów qumrańskich ma charakter komentarza do Księgi Rodzaju, zawiera aluzje i reminiscencje lub parafrazuje materiał biblijny. Do najważniejszych zwojów nawiązujących do Rdz 12-50 należą: Apokryf Księgi Rodzaju (1QapGen), Przeredagowany Pięcioksiag (4Q158, 4Q364-367), Peszer do Księgi Rodzaju (4Q252, 4Q254), Apokryf Ksiegi Jubileuszów (4Q225-226), Wykład na temat patriarchów (4Q464), Parafraza Księgi Rodzaju i Księgi Wyjścia (4Q422), Tekst dotyczacy Racheli i Józefa (4Q474), Testament Neftalego (4Q215), Testament Jakuba (4Q537), Testament Judy (4Q538), Testament Józefa (4Q539).

Ze względu na bardzo obszerny materiał dotyczący Rdz 12-50, obecny w zwojach qumrańskich, w niniejszym artykule zostaną przedstawione wybrane fragmenty tekstów interpretujących biblijne opowiadania o patriarchach: Abrahamie, Izaaku i Jakubie.

\section{Trzej patriarchowie wspominani razem}

W niebiblijnych zwojach z Qumran patriarchowie często występują razem w klasycznej sekwencji wspominającej ich imiona: Abraham, Izaak i Jakub (4Q225 frag. 2, kol. 2, linia 12; 4Q226 frag. 7, linia 5; 4Q379 frg. 17, linia 4; 4Q388a frag. 7, kol. 2, linia 2; 4Q389 frag. 8, kol. 2, linie 8-9; 4Q393 frag. 4, linia 5; 4Q505 frag. 124, linia 6; 4Q508 frag. 3, linia 3).

W Dokumencie Damasceńskim wszyscy trzej patriarchowie są wspomniani jako wzór wierności Bogu (CD 3,2-4): ${ }^{4}$

3 Zob. E. Tov, Revised Lists of the Texts from the Judaean Desert, Leiden-Boston 2010, s. 113-114, 126; zob. też A. Tr o n i n a, Biblia w Qumran. Wprowadzenie w lekturę biblijnych rękopisów znad Morza Martwego, BZ.TNT 8, Kraków 2001, s. 54-55; P. M u c h o w s k i, Komentarze do rękopisów znad Morza Martwego, Seria Judaica i Hebraica 1, Poznań 2005, s. 338-340, 343-345.

4 Zob. tekst hebrajski wraz z tłumaczeniem na język angielski: J.M. B a u m g a r t e n, D.R. S c h w a r t z,Damascus Dokument (CD), w: J. C h a r l e s w o r t h $\mathrm{i}$ in. (red.), The Dead Sea Scrolls. Hebrew, Aramaic, and Greek Texts with English 
„Abraham nie kroczył w niej [tj. w zatwardziałości serca], i sta się przyjacielem z powodu zachowywania przykazań Boga, i nie wybierał

według woli swego ducha. I przekazał [przykazania] Izaakowi i Jakubowi, a oni przestrzegali [ich] i zostali zapisani jako przyjaciele

4 Boga i posiadający przymierze na zawsze".

Postawa wierności patriarchów jest ukazana w kontekście opisu tych, którzy, postępując w twardości swoich serc, upadli i nie przestrzegali przykazań Boga (CD 2,14-3,12). Opis przeciwstawienia dwóch postaw wobec Boga rozpoczyna autor $\mathrm{CD}$, nawiązując do terminologii mądrościowej: „A teraz, synowie, słuchajcie mnie! Otworzę wasze oczy, abyście widzieli, i abyście rozumieli dzieła Boga, i abyście wybierali to, czego On pragnie, i odrzucali to, co On nienawidzi. Abyście kroczyli doskonale wszystkimi Jego drogami i nie dali się zwieść przez myśli o grzesznej skłonności i oczom nierządu. Bo wielu zbłądziło z ich powodu i dzielni wojownicy potknęli się o nie, od dawna aż do teraz" (CD 2,14-17). Wśród tych, którzy okazali się niewierni Bogu są „strażnicy niebios” (CD 2,18), ich potomstwo, a więc olbrzymi (CD 2,19), pokolenie ludzi ukaranych potopem (CD 2,20-21), pokolenie żyjące w niewoli egipskiej i wędrujące przez pustynię (CD 3,5-9) oraz wszyscy, którzy grzeszyli od czasu zajęcia Kanaanu aż po zburzenie Jerozolimy przez Babilończyków (CD 3,912).

W przeciwieństwie do tych, którzy sprzeniewierzali się woli Boga, zostali ukazani Abraham, a po nim także Izaak i Jakub. Trzej

Translations, The Princeton Theological Seminary Dead Sea Scrolls Project, t. 2: Damascus Document, War Scroll, and Related Documents, Tübingen-Louisville 1995, s. 16-17; por. W. Ty l o c h, Rękopisy z Qumran nad Morzem Martwym, Warszawa 1997, s. 196; P. M u c h o w s k i, Rękopisy znad Morza Martwego: Qumran, Wadi Murabba'at, Masada, Nachal Chewer, BZ.TNT 5, Kraków 2000, s. 201. 
patriarchowie są przedstawieni jako ci, którzy przestrzegali przykazań, a więc postępowali nie według własnej woli, ale we wszystkim okazywali posłuszeństwo Bogu. ${ }^{5}$ Warto zwrócić uwagę, że są oni obdarzeni zaszczytnym tytułem ,przyjaciół” Boga (w odniesieniu do Abrahama: אוהב; w odniesieniu do Izaaka i Jakuba:אוהבים). W obu przypadkach autor CD używa formy imiesłowowej pochodzącej od czasownika אהב (,miłować”, ,kochać”), która przybiera znaczenie rzeczownikowe, mianowicie „umiłowany”, tj. ,przyjaciel” (por. 4Q252 kol. 2, linia 8: o Abrahamie: אהבו, ,umiłowany Jego”; 4Q372 frag. 1, linia 21: o Jakubie: אהביך, ,umiłowany Twój”). ${ }^{6}$ Warto zauważyć, że Abraham jest nazwany przyjacielem Boga zarówno w Starym Testamencie (Iz 41,8; 2Krn 20,7), jak również w literaturze apokryficznej (Jub 17,18) oraz w Nowym Testamencie (Jk 2,23).

\section{Patriarcha Abraham}

W niebiblijnych zwojach qumrańskich - zarówno hebrajskich, jak i aramejskich - imię patriarchy Abrahama pojawia się 78 razy (w formie אברם - ,Abram”: 31 razy; w formie -,Abraham”: 47 razy). ${ }^{7}$ Oprócz tekstów, w których patriarchowie pojawiają się razem (najczęściej w standardowej sekwencji: Abraham, Izaak i Jakub), postać Abrahama występuje w kilku dokumentach, m.in. w Peszerze do Księgi Rodzaju (4Q252, 4Q254), Apokryfie Księgi Jubileuszów (4Q225-226), a przede wszystkim w aramejskim Apokryfie Księgi Rodzaju (1QapGen). Oprócz 1QapGen, pozostałe dokumenty zachowały się w stanie bardzo fragmentarycznym.

5 Zob. B.Z. W a c hold e r, The New Damascus Document. The Midrash on the Eschatological Torah of the Dead Sea Scrolls: Reconstruction, Translation and Commentary, STDJ 56, Leiden-Boston 2007, s. 175-176.

6 Zob. D.J.A. C 1 i n e s (red.), The Dictionary of Classical Hebrew, t. I, Sheffield 1993, s. 140.

7 Zob. M.G. A b e g g i in. (red.), The Dead Sea Scrolls Concordance, t. I: The Non-Biblical Texts from Qumran, cz. I-II, Leiden-Boston 2003 - w tekstach hebrajskich: „Abram” - 5 razy i „Abraham” - 43 razy, cz. I, s. 7; w tekstach aramejskich: „Abram” - 26 razy i „Abraham” - 4 razy, cz. II, s. 777. 
Peszer do Księgi Rodzaju (4Q252) ${ }^{8}$

Peszer ten zawiera kilka wzmianek o Abrahamie, ale z powodu źle zachowanego tekstu trudno stwierdzić cokolwiek pewnego o sposobie ukazania w tym dokumencie postaci patriarchy w porównaniu z materiałem biblijnym, a jedynie można wskazać na fragmenty odpowiadające treści z Księgi Rodzaju. Dokument, mający charakter peszeru do Księgi Rodzaju, zawiera cytaty tekstu biblijnego i komentarze do wybranych epizodów dotyczących osoby i wydarzeń z życia Abrahama. Ponieważ w 4Q252 podejmowane są tylko niektóre wątki odnoszące się do Abrahama, dlatego nie jest oczywiste kryterium wyboru podejmowanego przez autora qumrańskiego, mianowicie dlaczego podejmuje jedne motywy a pomija inne, gdyż sekwencja zdarzeń nie zawsze odpowiada tej, która znajduje się w materiale biblijnym.

Kilka epizodów związanych z osobą i życiem Abrahama pojawia się w 4Q252 kol. 2 oraz kol. 3.

4Q252 kol. 2:

7 ,gdyż Bóg pobłogosławił synów Noego i będzie On mieszkać w namiotach Sema,

8 ziemię dał Abrahamowi, umiłowanemu Jego. (vacat) Terach miał sto czte[rdz]ieści lat, gdy wyszedł

9 z Ur Chaldejczyków i przybył do Charanu. I Ab[ram miał] siedemdziesiąt lat. I pięć lat mieszkał

8 Wydanie tekstu: G. B r o o k e, 252. 4QCommentary on Genesis A, w: t e n ż e i in. (red.), Qumran Cave 4.XVII: Parabiblical Texts, Part 3, DJD 22, Oxford 1996, s. 185-207 (+ pl. XII-XIII); J.L. Tr a f to n, Commentary on Genesis A 4 Q252 = $4 Q$ CommGen $A=4 Q P B l e s s), w:$ J.H. C h a r le s w o r t h i in. (red.), The Dead Sea Scrolls. Hebrew, Aramaic, and Greek Texts with English Translations, PTSDSSP, t. 6B: Pesharim, Other Commentaries, and Related Documents, Tübingen-Louisville 2002, s. 203-219. 
10 Abram w Charanie. I po wyjściu [...] ziemia Kanaan, sześćdz[iesiąt...]

11 jałówkę, barana i ko[zę...] Abram dla [...]

12 ogień gdy przechodził [...] wziął [...]

13 przy wyjściu Abra[ma...] Kanaan".

Pierwsza wzmianka o Abrahamie pojawia się w sekcji poświęconej uprawie winnej latorośli przez Noego i konsekwencji wynikłych z nadużycia przez niego wina (kol. 2, linie 5-8; Rdz 9,20-27). Wyjaśniając, dlaczego Noe przeklął Kanaana zamiast jego ojca Chama, autor qumrański stwierdza, że Bóg będzie błogosławić Sema i jego potomków. W zakończeniu tego wyjaśnienia - czego brak w materiale biblijnym - wspomina się o tym, że Bóg dał ziemię Abrahamowi, który został tu obdarzony zaszczytnym tytułem ,przyjaciela Boga”. Użyty termin wbha, dosł. „umiłowany Jego” (kol. 2, linia 8), wyraża - podobnie jak w Jub 17,18, CD 3,2 - wierność Abrahama wobec przymierza przez zachowywanie Bożych przykazań. ${ }^{9}$ Wydaje się, że forma wzmianki o Abrahamie nawiązuje do 2Krn 20,7, gdzie król Jozafat w obliczu zagrożenia spowodowanego najazdem Moabitów i Ammonitów na Judę modli się do Boga: „Czy to nie Ty, Boże nasz, wygnałeś mieszkańców tej ziemi przed Twoim ludem, Izraelem, i dałeś ją na wieki potomstwu Abrahama, przyjaciela Twego?"10 Pojawia-

9 Zob. M. S e g a 1, The Book of Jubilees: Rewritten Bible, Redaction, Ideology, and Theology, JSJSup 117, Leiden-Boston 2007, s. 299; M.J. B e r n s t e i n, Where Are the Patriarchs in the Literature of Qumran? w: D. D i m a n t, R.G. K r a t z (red.), Rewriting and Interpreting the Hebrew Bible: The Biblical Patriarchs in the Light of the Dead Sea Scrolls, BZAW 439, Berlin 2013, s. 55; szerzej na ten temat, zob. R.G. K r a t z Friend of God, Brother of Sarah, and Father of Isaac: Abraham in the Hebrew Bible and in Qumran, w: D. D i m a n t, R.G. K r a t z (red.), The Dynamics of Language and Exegesis at Qumran, FAT 35, Tübingen 2009, s. 80-87.

10 Zob. G. B r o o k e, 252. 4QCommentary on Genesis A, s. 200; t e n ż e, The Thematic Content of 4Q252, JQR 85/1994, s. 43; t e n ż e, Genesis, Commentary on, 
jąca się w 4Q252 kol. 2, linii 8 wzmianka o Abrahamie łączy ze sobą dwa odrębne tematy, mianowicie motyw ziemi danej Abrahamowi i jego potomkom przez Boga oraz ukazanie patriarchy jako ,,przyjaciela Boga" (zob. Iz 41,8; 2Krn 20,7; 4Q176 frag. 1-2, kol. 1, linia 9). ${ }^{11}$

W linii 8 - po wzmiance o „Abrahamie, umiłowanym Jego" następuje w tekście qumrańskim przerwa (tj. vacat), co sugeruje początek nowej sekcji, której treścią jest wędrówka Teracha z Ur Chaldejczyków do Charanu (Rdz 11,31-32) oraz podróż Abrahama do Kanaanu (Rdz 12,4). Autor 4Q252 przedstawia chronologię życia Teracha i Abrahama inaczej niż w Księdze Rodzaju, mianowicie ukazuje ją w sposób bardziej precyzyjny. ${ }^{12}$ Podczas gdy w Księdze Rodzaju stwierdza się ogólnie, że Terach żył dwieście pięć lat i umarł w Charanie (Rdz 11,32), to w 4Q252 mówi się, że miał sto czterdzieści lat, gdy wyruszył z Ur i przybył do Charanu (linia 8). W linii 10 pojawia się słowo „sześćdziesiąt”, ale, niestety, dalsza część tekstu nie zachowała się, można jedynie przypuszczać, że ta wzmianka odnosi się do liczby lat, które Terach spędził w Charanie. ${ }^{13}$ Jeśli ta sugestia byłaby słuszna, to można by uzupełnić uszkodzony tekst jako „sześćdz[iesiąt pięć...]”, co byłoby zgodne z biblijnymi danymi odnośnie do długości życia Teracha. Zgodnie z przekazem Rdz 12,4 Abraham miał siedemdziesiąt pięć lat, gdy wyruszył z Charanu, natomiast w 4Q252 stwierdza się, że miał on siedemdziesiąt lat, gdy

w: L.H. S c h if f m a n, J.C. V a n d e r K a m i in. (red.), Encyclopedia of the Dead Sea Scrolls, t. I, s. 300; D.K. F a 1 k, The Parabiblical Texts: Strategies for Extending the Scriptures among the Dead Sea Scrolls, Companion to the Dead Sea Scrolls 8, Library of Second Temple Studies 63) London 2007, s. 131-132; M. P o p o v i ć, Abraham and the Nations in the Dead Sea Scrolls: Exclusivism and Inclusivism in the Texts from Qumran and the Absence of a Reception History for Gen 12:3, w: M. G o o d m a n i in. (red.), Abraham, the Nations, and the Hagarites: Jewish, Christian, and Islamic Perspectives on Kinship with Abraham, Themes in Biblical Narrative 13, Leiden-Boston 2010, s. 83-84.

1 Zob. G. B r o o ke, The Thematic Content of 4Q252, s. 43; M. P o p o v i ć, Abraham and the Nations in the Dead Sea Scrolls, s. 83.

12 Zob. G. B r o o k e, Genesis, Commentary on, s. 301.

13 Zob. te n ż e, 252. 4QCommentary on Genesis A, s. 200; M. P o p o v i ć, Abraham and the Nations in the Dead Sea Scrolls, s. 83. 
przybył razem ze swoim ojcem Terachem do Charanu, a następnie mieszkał tam przez pięć lat.

Tekst w 4Q252 kol. 2, liniach 11-13 zachował się w stanie bardzo fragmentarycznym, ale z odczytanych słów można wnioskować, że ten fragment odpowiada opisowi przymierza, które Bóg zawarł z Abrahamem (Rdz 15). W linii 11 (,,jałówkę, barana i ko[zę...] Abram dla [...]”) pojawia się słownictwo jak w Rdz 15,9: „I powiedział do niego: Weź dla Mnie jałówkę trzyletnią, i kozę trzyletnią, i barana trzyletniego, i synogarlicę, i gołębia”, natomiast treść linii 12 („ogień gdy przechodził [...] wziął [...]”) nawiązuje do Rdz 15,17: „I stało się, że słońce zaszło, i nastała ciemność, i oto dym z pieca i pochodnia ognia, który przeszedł między tymi częściami”.

4Q252 kol. 3:

$1 \quad$,jak zostało napisane [...] dwu-

2 nastu ludz[i... Gomo]ra i również

3 to miasto (...) sprawiedliwych

$4 \quad$ Ja $[\ldots]$ oni sami zniszczą.

5 I jeśli nie znajdą się tam [... i wszystko,] co się w nim znajduje, i łup jego,

6 i dzieci jego, i resztę [...] zawsze. I wyciągnął

7 Abraham swoją rękę [... nie]biosa

8 i powiedział do niego: Te[raz...]

9 twój jedyny". 
Chociaż tekst zachował się w bardzo fragmentarycznym stanie, to jednak można w nim wyodrębnić kilka epizodów związanych z Abrahamem.

Treść w liniach 1-2 najprawdopodobniej odnosi się do błogosławieństwa, które Bóg obiecuje Izmaelowi i jego potomkom (Rdz 17,20). ${ }^{14} \mathrm{~W}$ tekście biblijnym Bóg oznajmia Abrahamowi: „A co do Izmaela, wysłucham cię: Oto pobłogosławię go, i uczynię go płodnym, i rozmnożę go bardzo. Dwunastu książąt zrodzi, i uczynię go narodem wielkim". Trudno jednak z całą pewnością stwierdzić, czy taka identyfikacja jest słuszna, ponieważ w Rdz 17,20 jest mowa o „dwunastu książętach” (שנים עשר נשיאם), którzy będą potomkami Izmaela, natomiast w 4Q252 mówi się o „dwunastu ludziach” ( שנשים (שנים עשר się w linii 1 jest słabo czytelne. ${ }^{15}$

W liniach 2-6 bez wątpienia pojawia się aluzja do zniszczenia Sodomy i Gomory (Rdz 18,20-33). ${ }^{16}$ Wprawdzie nazwa miasta nie zachowała się w całości, ale jej rekonstrukcja, tj. ,[...Gomo]ra” wydaje się w tym miejscu uzasadniona (linia 2 ), ${ }^{17}$ ponieważ dalsza treść znajdująca się w liniach 3-6 zawiera słownictwo występujące w Rdz 18,29-32. Biblijny opis zniszczenia Sodomy i Gomory jest w 4Q252 interpretowany w świetle przepisów dotyczących postępowania wobec miasta obłożonego klątwą za bałwochwalstwo jego mieszkańców z Pwt 13,13-17 (zob. też 20,11.14).

14 Tak uważają, m.in. G. B r o o k e, Genesis, Commentary on, s. 301; M. P o p o v i ć, Abraham and the Nations in the Dead Sea Scrolls, s. 82.

15 G. B r o o k e, 252. 4QCommentary on Genesis A, rekonstruuje jako שֶנים עשר „dwunastu”, natomiast J.L. T r a f t o n Commentary on Genesis A, pozostawia jako nieczytelne: נים עשר (...), ,njm dziesięciu” .

16 Tak sądzą, m.in. J.L. T r a f t o n Commentary on Genesis A, s. 214; G. B r o o k e, Genesis, Commentary on, s. 301; M. P o p o v i ć, Abraham and the Nations in the Dead Sea Scrolls, s. 82; M.J. B e r n s t e i n, Where Are the Patriarchs, s. 54.

${ }_{17} \mathrm{~W}$ ten sposób rekonstruują tekst G. Brooke oraz J.L. Trafton. 
Treść linii 6-9 odnosi się do ofiarowania Izaaka (Rdz 22,1-19). ${ }^{18}$ Na taką identyfikację wskazuje wyrażenie ,i wyciągnął Abraham swoją rękę [...]" (linie 6-7), które w identycznej formie pojawia się w Rdz 22,10: „I wyciągnął Abraham swoją rękę, i wziął nóż, aby zabić swego syna”. Zachowane w linii 7 słowo „[... z nie]bios” może odnosić się do treści z Rdz 22,11: „I zawołał do niego anioł JHWH z niebios, i powiedział: Abrahamie, Abrahamie! A on powiedział: Oto jestem”. Treść linii 8-9 stanowi aluzję do Rdz 22,12: „I powiedział: Nie wyciągaj swojej ręki na chłopca i nie rób mu nic, bo teraz wiem, że jesteś bojącym się Boga i nie odmówiłeś Mi swego syna, swego jedynego”, na co wskazuje słowo „te[raz]” (linia 8) oraz określenie Izaaka jako ,jedyny twój”" ( יחידכה, linia 9), które ma identyczną formę jak w Rdz 22,12 (יחירך).

Apokryf Księgi Jubileuszów (4Q225) ${ }^{19}$

Jest to kompozycja parafrazująca tekst biblijny z Ksiąg Rodzaju i Wyjścia, czym wykazuje pewne podobieństwo do apokryficznej Księgi Jubileuszów. Dokument 4Q225, datowany na koniec I w. przed Chr. lub początek I w. po Chr., zachował się w postaci pięciu fragmentów.

Tekst frag. 1 zachował się w stanie szczątkowym, ale wyraźna wzmianka o Abrahamie pojawia się w linii 4: ,,...] zostało zawarte z Abrahamem. I jedli [...]”. Słowa te ( נכרתה עם אברהם) odnoszą się bez wątpienia do przymierza, które Bóg zawarł z patriarchą. ${ }^{20}$ Brak kon-

18 Tak uważają, m.in. J.L. Tr a ft on Commentary on Genesis A, s. 214-215; G. B r o o k e, Genesis, Commentary on, s. 301; M. P o p o v i ć, Abraham and the Nations in the Dead Sea Scrolls, s. 82; M.J. B e r n s t e i n, Where Are the Patriarchs, s. 54.

19 Wydanie tekstu: J. V a n d e r K a m, J.T. M i 1 i k, 225. 4QpseudoJubilees a, w: H. Attridge i in. (red.), Qumran Cave 4.VIII: Parabiblical Texts, Part 1, DJD 13, Oxford 1994, s. 141-155 (+ pl. X); zob. też R.A. K u g l e r, J.C. V a n d e r K a m, A Note on 4Q225 (4QPseudo-Jubilees), RQ 20/2001, s. 109-116.

20 Zob. C.A. Ev a n s, Abraham in the Dead Sea Scrolls: A Man of Faith and Failure, w: P.W. F 1 i n t (red.), The Bible at Qumran: Text, Shape, and Interpretation, SDSSRL, Grand Rapids-Cambridge 2001, s. 157. 
tekstu uniemożliwia jednak formułowanie jakichkolwiek wniosków wiążących to wyrażenie z jakimś konkretnym tekstem biblijnym (może Rdz 15?). ${ }^{21}$

O kilku epizodach z życia Abrahama jest mowa w frag. 2, którego tekst zachował w stosunkowo dobrym stanie.

4Q225, frag. 2, kol. 1, linie 3-9:

„[I powiedział A]braham do Boga: Panie, oto przychodzę

3 bezdzietny, a Eli[ezer]

[...] on i będzie moim dziedzicem (vacat)

4

[Powiedział P]an do Abrahama: Podnieś [oczy], spójrz na

5 gwiazdy i zobacz (...)

$6 \quad$ [...] piasek, który jest na brzegu morza, i proch ziemi, bo jeśli [...] te, i jeśli nie, takie będzie twoje potomstwo będzie. 7 I uwi[erzył]

8 [Abraham] Bogu, i zostało mu to policzone jako sprawiedliwość. I urodził się syn po tym

9 [Abraha]mowi, i nazwał go imieniem Izaak".

Treść linii 3-9 nawiązuje do dialogu Abrahama z Bogiem w Rdz 15,2-6, przy czym tekst w 4Q225 jest dość luźną parafrazą materiału biblijnego, w której pojawia się również nieco inna aranżacja

${ }^{21}$ Zob. M.J. B e r n s te i n, Contours of Genesis Interpretation at Qumran: Contents, Context, and Nomenclature, w: t e $\mathrm{n} \dot{\mathrm{z}} \mathrm{e}$, Reading and Re-Reading Scripture at Qumran, t. I: Genesis and Its Interpretation, STDJ 107/1, Leiden-Boston 2013, s. 71; warto zwrócić uwagę, że wydawca 4Q225 w DJD 13 (J. V a n d e r K a m, J.T. M i 1 i k, 225. 4QpseudoJubilees $a$, s. 143-144) odczytał tekst w linii 4 jako „(...) zostało zawarte z Abrahamem. I obrzezał (...)", jednak ponowne odczytanie tego tekstu (R.A. K u g l e r, J.C. V a n d e r K a m, A Note on 4Q225) doprowadziło do odczytania ostatniego wyrażenia nie jako ,i obrzezał [ וימו ]", ale jako ,, jedli [יויאכלי]". 
wydarzeń. W 4Q225 Abraham stwierdza, że z powodu braku potomka jego dziedzicem zostanie Eliezer (linie 3-4), podczas gdy w Rdz 15,2-3 patriarcha mówi o podeszłym wieku i braku potomstwa jako powodach tego, że spadkobiercą jego majętności będzie Eliezer Damasceńczyk. W tekście qumrańskim po pustym miejscu (vacat) w linii 4, Bóg odpowiada Abrahamowi, obiecując mu liczne potomstwo (linie 5-7). Podczas gdy w Rdz 15,5 liczebność potomstwa jest porównana jedynie do gwiazd, to autor 4Q225 wzbogaca tekst i, mówiąc o liczebności potomstwa, łączy kilka wątków związanych z błogosławieństwem wobec Abrahama, mianowicie Rdz 15,5 (gwiazdy), Rdz 22,17 (piasek na brzegu morza) oraz Rdz 13,16 (proch ziemi). Dialog kończy się stwierdzeniem, że Abraham uwierzył, co zostało mu policzone jako sprawiedliwość (linie 7-8; Rdz 15,6: „I uwierzył JHWH, i zostało mu to policzone za sprawiedliwość”). Bezpośrednio po tym stwierdzeniu w 4Q225 pojawia się wzmianka o urodzeniu się Izaaka, o czym w materiale biblijnym jest mowa dopiero w Rdz 21. Wydaje się, że narodziny Izaaka są przez autora 4Q225 postrzegane jako swoistego rodzaju nagroda dla Abrahama za jego sprawiedliwość. ${ }^{22} \mathrm{~W}$ dalszej części tekstu (kol. 2, linia 9-kol. 3) jest mowa o ofiarowaniu Izaaka, co zostanie omówione w części niniejszego artykułu poświęconej temu patriarsze.

\section{Apokryf Księgi Rodzaju (1QapGen; 1Q20) $)^{23}$}

Jest to aramejski dokument datowany na początek I w. po Chr., który został skomponowany najprawdopodobniej w pierwszych latach I w. przed Chr. lub wcześniej. Zawiera pozostałości dwudziestu trzech

22 Zob. M.J. B e r n s t e i n, Where Are the Patriarchs, 57.

$23 \mathrm{Z}$ bogatej literatury na temat 1 QapGen, zob. D.K. F a $1 \mathrm{k}$, The Parabiblical Texts, s. 26-106; J.A. F it z m y e r, The Genesis Apocryphon from Qumran Cave 1 (1Q20): A Commentary, BiOr 18B, Roma 2004; D.A. M a c h i e la, The Dead Sea Genesis Apocryphon: A New Text and Translation with Introduction and Special Treatment of Columns 13-17, STDJ 79, Leiden-Boston 2009; A. T r o $n$ i n a, Wokót Biblii w Qumran. Od targumu (11Q10) do midraszu (1Q20), BZ.TNT 15, Kraków-Mogilany 2012, s. 57-160. 
kolumn tekstu, w którym można wyodrębnić trzy sekcje poświęcone Lamekowi (kol. 0-5), Noemu (6-18,23) i Abramowi $(18,24-22,34)$. Treścią 1QapGen są opowieści o patriarchach przedstawiające w chronologicznym porządku wydarzenia opisane w Księdze Rodzaju. Tekst dokumentu stanowi parafrazę materiału biblijnego, w czym przypomina inne pisma o charakterze parabiblijnym, zwłaszcza Księge Jubileuszów.

W 1QapGen znajduje się najwięcej materiału poświęconego Abrahamowi spośród wszystkim zwojów odnalezionych w Qumran, bo prawie cztery kolumny tekstu $(18,24-22,34)$, co jest parafrazą $\mathrm{Rdz} 12-15 .{ }^{24} \mathrm{~W}$ całym dokumencie w odniesieniu do patriarchy jest używana forma imienia „Abram”. W tej części dokumentu, która odnosi się do Abrama, można wyodrębnić kilka epizodów: ${ }^{25}$

- powołanie, wyjście z Ur i pobyt w Charanie (kol. 18);

- $\quad$ pobyt w Betel i Hebronie (kol. 19,1-10);

- $\quad$ pobyt w Egipcie (kol. 19,10-20,32); składa się z kilku elementów: wędrówka do Egiptu (19,10-13), sen o cedrze i palmie (19,14-23), wizyta dostojników egipskich (19,23-27), zabranie Sary na dwór faraona (19,27-20,11), modlitwa Abrahama o ochronę Sary (20,12-16), choroba faraona i jego uzdrowienie (20,16-31), opuszczenie Egiptu (20,31-33);

- $\quad$ pobyt w Kanaanie (20,33 - 21,22); składa się z kilku wątków: powrót razem z Lotem do Betel $(20,33-21,4)$, oddzielenie się Lota i osiedlenie w Sodomie (21,5-7), wizja senna o obietnicy Boga względem ziemi (21,8-14), obchód Ziemi Obiecanej $(21,15-22)$;

24 Treść kol. 18 jest nieczytelna, ale zachował się odstęp między liniami wskazujący na początek nowej sekcji poświęconej Abramowi. Można przypuszczać, że treść w tej kolumnie dotyczyła powołania Abrama, jego wyjścia z Ur i pobytu w Charanie, zob. D.A. M a c h i e l a, On the Importance of Being Abram: Genesis Apocryphon 18, Jubilees 10:1 - 13:4, and Further Thoughts on Literary Relationship, w: E.F. M a s o n i in. (red.), A Teacher for All Generations. Fs. J.C. VanderKam, JSJSup 153, t. II, Leiden 2012, s. 715-736.

${ }_{25}$ Zob. P. M u c h ow s k i, Komentarze do rękopisów znad Morza Martwego, s. 252-253; A. Tro n i n a, Wokót Biblii w Qumran, s. 143-160. 
- Abram zwycięża czterech królów Wschodu (21,23 - 22,26); składa się z kilku elementów: wojna czterech królów Mezopotamii przeciwko pięciu królom kananejskim (21,23-30), niewola i uwolnienie Lota $(21,31$ - 22,12), Melchizedek, król Salemu (22,12-17), spotkanie Abrama z królem Sodomy (22,18-26);

- wizja, w której Bóg obiecuje Abramowi dziedzica - zapowiedź narodzin Izaaka (22,27-34).

1QapGen nie tylko parafrazuje tekst z Rdz 12-15, ale również wzbogaca materiał biblijny różnego rodzaju dodatkami. Gdy chodzi o osobę Abrama, to należy zauważyć, że w tym dokumencie w bardziej wyrazisty sposób niż w Księdze Rodzaju podkreśla się niektóre jego cechy i przymioty. Warto zwrócić uwagę na ukazanie Abrama jako mędrca.

W kol. 19, liniach 23-29 Abram jest ukazany jako wzór mędrca, który przekazuje swoją wiedzę Egipcjanom.

1QapGen kol. 19, linie 23-29:

„I po tych pięciu latach

[...] do mnie, i trzej mężowie spośród dostojników Egiptu

24 [...] faraona Soanu z powodu moich słów i z powodu mojej mądrości, a oni dali

25 [... i pr]osili dla siebie o wiedzę pisarską i mądrość i prawdę, a ja czytałem przed nimi księgę słów Henocha

26 [...] w łonie, w którym wzrastał. A oni nie odchodzili, dopóki nie wyjaśniłem im jasno [...] stów

27 [...] wiele jedząc i wiele pijąc [...] wino

$28 \quad[\ldots]$ tobie, ja $[. .$.

29 [...] wchodził [...] i powiedziałem do [...] do Soanu, przez [...] wszystkie słowa Henocha". 
Opisane wydarzenie miało miejsce w piątym roku pobytu Abrama w Egipcie (linia 23). Tekst zachował się w stanie bardzo fragmentarycznym, ale z jego treści wynika, że faraon wysłał do Abrama trzech swoich dostojników, aby prosić go o przekazanie wiedzy i mądrości. Można przypuszczać, że powodem tego była sława mądrości, jaką cieszył się patriarcha, a która dotarła również na dwór faraona. $\mathrm{Na}$ takie rozumienie może wskazywać wyrażenie על מלי ועל חכמתי „,z powodu moich słów i z powodu mojej mądrości” (linia 24). Wiedza i mądrość Abrama zostały określone za pomocą trzech aramejskich terminów (linia 25). Pierwszy z nich, mianowicie ספר taj „wiedzę pisarską”, „biegłość w korzystaniu z mądrości zawartej w księgach”, „erudycję” (por. rps, „rzemiosło pisarskie” w 4Q213 frag. 1, kol. 1, linii 9 [= Aramejski Dokument Lewiego, ALD 90]). Kolejne dwa terminy, mianowicie „mądrośćc” חושטא , חכמת i ,prawda wskazują nie tylko na wiedzę i mądrość, ale również na prawość, pobożność i doskonałość. Ponadto dwukrotna wzmianka o „słowach Henocha" (linie 25 i 29) może wskazywać na biegłość Abrama w tajemnej wiedzy i mądrości o charakterze mantycznym. Warto zwrócić uwagę, że przypisywanie mądrości Abrahamowi, który przekazuje wiedzę Egipcjanom, pojawia się również u historyków żydowskich: Pseudo-Eupolemosa z III w. przed Chr., którego tekst zachował się u Euzebiusza z Cezarei (Praeparatio Evangelica, 9,17) oraz Józefa Flawiusza z I w. po Chr. (Antiquitates, 1,165-168). ${ }^{26}$

\section{Patriarcha Izaak}

W zwojach odnalezionych w Qumran - podobnie jak w Księdze Rodzaju - postać Izaaka nie cieszy się zbyt dużym zainteresowaniem. ${ }^{27}$ Wprawdzie jego imię pojawia się 30 razy w niebiblijnych

26 Zob. J.A. F it z m y e r, The Genesis Apocryphon from Qumran Cave 1 (1Q20): A Commentary, s. 191; A. Tr o n i n a, Wokót Biblii w Qumran, s. 146-147.

27 Warto zauważyć, że w encyklopedii poświęconej zwojom z Qumran (L.H. S c h iff m a n, J.C. V a n d e r K a m / red./, Encyclopedia of the Dead Sea Scrolls, t. I-II) brak hasła „Izaak”, ale znajdują się hasła „Abraham” i „Jakub”. 
tekstach qumrańskich (w różnych formach: ישחק , יסחק, ${ }^{28}$ to jednak najczęściej występuje ono w sekwencji wymieniającej wszystkich trzech patriarchów (tj. gdy jest mowa o przymierzu z Abrahamem, Izaakiem i Jakubem), albo jest o nim mowa w relacji do ojca, a więc wspomina się o nim jako o „synu Abrahama” (zob. np. 4Q180 frag. 1, linie 4-5; 4Q181, frag. 2, linia 1; 4Q364 frag. 1, linia 2). Jedynym wydarzeniem, któremu poświęca się więcej uwagi, jest ofiarowanie Izaaka (4Q225). ${ }^{29}$

Obszerny opis ofiarowania Izaaka znajduje się w Apokryfie Księgi Jubileuszów (4Q225 frag. 2, kol. 1, linia 9 - kol. 2, linia 14):

kol. 1:

9

10

11

12

13

14

„Wtedy przybył książę wrogości

[do Bo]ga, i oskarżył Abrahama z powodu Izaaka. I powiedział Bóg:

[do Abra]hama: Weź twego syna, Izaaka, jedynego [twego, którego]

[miłuj]esz, i złóż Mi go jako ofiarę całopalną na jednej z [wysokich] gór

[o której powiem] ci. I powst[ał, i po]szedł od studni do [...]

[...] i uniósł $\mathrm{Ab}[\mathrm{raham}] "$

28 Zob. M.G. A begg i in. (red.), The Dead Sea Scrolls Concordance, t. I (w tekstach hebrajskich: 26 razy, cz. I, s. 323; w tekstach aramejskich: 4 razy, cz. II, s. 848).

${ }_{29}$ Zob. M.J. B e rn ste i n, Where Are the Patriarchs, s. 62-65; F. G a r cía Martín e z, The Sacrifice of Isaac in 4Q225, w: E. N o o r t, E. Ti g c h e l a a r (red.), The Sacrifice of Isaac: The Aqedah (Genesis 22) and Its Interpretation, Themes in Biblical Narrative 4, Leiden 2002, s. 44-45; więcej na temat Izaaka w Qumran, zob. H.-J. F a b r y, Isaak in den Handschriften von Qumran, w: F. G a r c í a Martín e z i in. (red.), From 4QMMT to Resurrection. Fs. E. Puech, STDJ 61, Leiden-Boston 2006, s. 87-103; G.J. B r o o k e, Further Thoughts on Isaac in the Scrolls from the Qumran Caves, w: A.B. P e r r i n i in. (red.), Reading the Bible in Ancient Traditions and Modern Editions. Studies in Memory of Peter W. Flint, SBL.EJIL 47, Atlanta 2017, s. 381-399. 
kol. 2:

1

2

3

4

6

7

8

9

10

11

12

13

14

,[i powiedział] Izaak do Abrahama [...]

na ofiarę całopalną? I powiedział Abraham do [...]

dla siebie. I powiedział Izaak do swego ojca [...]

aniołowie świętości stali płacząc nad [...]

jego syna z ziemi. I aniołowie wr[ogości...]

radowali się i mówili: Teraz zginie. I [... jeśli]

zostanie znaleziony słabym, i jeśli nie zostanie znaleziony wiernym [...]

Abrahamie, Abrahamie! I powiedział: Oto jestem. I powiedział: Te[raz...]

nie będzie miłowany. I Bóg, JHWH, błogosławił Iza[aka...]

Jakuba, a Jakub zrodził Lewiego [...]

dni Abrahama, Izaaka, Jakuba i Lew[iego...]

i książę wrogości został związany [...]

książę wrogości, i Belial stuchat [...]”

Chociaż tekst jest w dość znacznym stopniu uszkodzony, to można stwierdzić, że prezentuje on parafrazę materiału biblijnego, w której autor 4Q225 z jednej strony pomija wiele elementów opowiadania z Rdz 22 (m.in. obecność sług, podjęcie próby złożenia Izaaka $\mathrm{w}$ ofierze, ofiarowanie barana zamiast Izaaka), a z drugiej dodaje nowe elementy, a zwłaszcza postacie (tj. książę wrogości, aniołowie 
świętości, aniołowie wrogości) pełniących ważną rolę w całym tym wydarzeniu, których brak w Rdz 22.

Według autora 4Q225, przyczyną poddania Abrahama próbie mającej wykazać jego wierność było działanie שר המשטמה (,księcia wrogości”) (kol. 1, linie 9-10). Ten sam rdzeń, שטה (,żywić urazę do kogoś”, „czuć wrogość do kogoś”), został użyty w nazwie istoty demonicznej ( משטמה - ,Wrogość”, „Mastema”, dosł. „wrogo nastawiony”, „ten, który nienawidzi”), ${ }^{30}$ jak i w czasowniku określającym jej działania skierowanego przeciwko Abrahamowi ( וישיטים - ,i oskarżył"). Bez względu na to, czy działanie księcia wrogości polegało na oskarżeniu, czy też na otwartym ataku, to zostało ono podjęte z nienawiści do Abrahama z powodu Izaaka (kol. 1, linia 10). Podobny motyw pojawia się w Księdze Jubileuszów: „Wtedy przybył książę Mastema i powiedział przed Bogiem: Oto Abraham kocha Izaaka, swego syna, i cieszy się nim bardziej niż kimkolwiek innym. Powiedz mu, aby złożył go jako ofiarę na ołtarzu. Wtedy zobaczysz, czy to zrobi, i będziesz wiedział, czy jest wierny we wszystkim, w czym poddałeś go próbie" (Jub 17,16; por. działanie szatana wobec Hioba w Hi 1,6-11; 2,1-5). Autor 4Q225 zwraca uwagę na powód oskarżenia Abrahama przez księcia wrogości, którym jest jego syn Izaak, na co wskazuje przyimek ב w wyrażeniu בישח, który może oznaczać ,z powodu (Izaaka)" lub ,ze względu na (Izaaka)”. Prawdziwym celem działania księcia wrogości jest nie tyle zazdrość lub chęć poddania Abrahama próbie, ale doprowadzenie do śmierci Izaaka (por. radość

30 Termin hmjfm pojawia się w zwojach z Qumran najczęściej w określeniu „posłaniec/anioł wrogości” w powiązaniu z Belialem (np. CD 16,3; 1QM 13,11; 4Q270 frag. 6, kol. 2, linia 18), natomiast w Księdze Jubileuszów występuje jako imię własne przywódcy złych duchów, szerzej na ten temat, zob. J.W. v a n H e n t e n, Mastemah, hmjfm, w: K. v a n d e r To o r $\mathrm{n}$ i in. (red.), Dictionary of Deities and Demons in the Bible, Leiden 1999, s. 553-554; J.L. K u g e 1, A Walk through Jubilees: Studies in the Book of Jubilees and the World of Its Creation, JSJSup 156, Leiden-Boston 2012, s. 82-84; D. D i m a n t, Between Qumran Sectarian and Qumran Nonsectarian Texts: The Case of Belial and Mastema, w: t e $\mathrm{n} \dot{\mathrm{z}} \mathrm{e}$, History, Ideology and Bible Interpretation in the Dead Sea Scrolls: Collected Studies, FAT 90, Tübingen 2014, s, 135-151. 
aniołów wrogości z jego śmierci w liniach 6-7), a tym samym unicestwienie planów Boga i uniemożliwienie wypełnienia się obietnicy danej Abrahamowi, która odnosiła się do zapewnienia patriarsze licznego potomstwa wywodzącego się właśnie od Izaaka. ${ }^{31} \mathrm{~W}$ ten sposób w 4Q225 podkreśla się niszczycielską działalność księcia wrogości, co ujawnia jego demoniczny charakter, gdyż występuje nie tylko przeciw Abrahamowi, ale przede wszystkim przeciwko samemu Bogu.

Kolejnym dodatkowym elementem w 4Q225, którego brak w Rdz 22, jest obecność istot niebiańskich. O ile w Rdz 22,11.15 podobnie jak w Jub 18,9-11 - występuje jeden ,posłaniec JHWH [ מלאך יהוה]", który objawia się Abrahamowi i powstrzymuje go od złożenia Izaaka w ofierze, to w 4Q225 pojawiają się ,posłańcy świętości [vdq ykalm]" (kol. 2, linia 5). Motyw wielu aniołów pojawia się w późniejszej literaturze, między innymi w Targumie Neofiti do Rdz 22,10: ,...i oczy Izaaka były skierowane na posłańców wysokości [במלאכי מרומא]", zaś w tradycji rabinicznej aniołowie są świadkami tego wydarzenia. Tekst zawierający wzmiankę o tym, że aniołowie świętości stoją i płaczą, jest uszkodzony. Warto jednak zauważyć, że o płaczących aniołach jest również mowa w Midraszu do Księgi Rodzaju, gdzie stwierdza się, że ich łzy spowodowały zniknięcie noża, co uniemożliwiło zabicie Izaaka (GenR 56,5-7). ${ }^{32}$

W kol. 2, linii 6 pojawiają się ,pposłańcy wrogości [ מלאכי המשטמה]”, tj. aniołowie Mastemy, których nie ma ani w materiale biblijnym (Rdz 22), ani też w późniejszych tekstach literatury żydowskiej. Najprawdopodobniej autor 4Q225 wspomina o obecności aniołów wrogości w tym celu, aby przeciwstawić ich aniołom świętości. ${ }^{33} \mathrm{Na}$ takie rozumienie wskazuje ich całkowicie odmienne zachowanie wobec zbliżającej się śmierci Izaaka, a mianowicie podczas gdy aniołowie

31 Zob. F. G a r cía M a rtín e z, The Sacrifice of Isaac in 4Q225, s. 50-51.

32 Zob. J. V a n d e r K a m, J.T. M i 1 i k, 225. 4QpseudoJubilees a, s. 152;

F. García Martín e z, The Sacrifice of Isaac in 4Q225, s. 54.

33 Zob. J. V a n d e r K a m, J.T. M i 1 i k, 225. 4QpseudoJubilees a, s. 152;

F. Gar cía Martín e z, The Sacrifice of Isaac in 4Q225, s. 55. 
świętości „płaczą” (kol. 2, linia 5), to aniołowie wrogości „radują się" (kol. 2, linia 7). Innymi słowy, autor 4Q225 wpisuje wydarzenie ofiarowania Izaaka w szerszy kontekst walki dobra ze złem. ${ }^{34}$

Na obecność niezwykle interesującego motywu w 4Q225 zwróלא ימצא נאמן לימצא כחש ואם nie znaleziony wiernym..." (linia 8) odnoszą się do Izaaka, a nie do Abrahama. Ponieważ podmiotem tekstu w poprzedniej linii 7 jest Izaak, którego bliska śmierć jest powodem radości aniołów wrogości, dlatego treść linii 8 wydaje się kontynuacją ich wypowiedzi. Autor 4Q225 w opisie postawy Izaaka używa dwóch określeń, które są przeciwstawne. Rdzeń כחש w formie czasownikowej oznacza ,pochylać” (qal), „udawać posłuszeństwo” (nifal), „mówić kłamstwa”, ,zawieść (kogoś)”, „udawać posłuszeństwo” ( piel), natomiast w formie rzeczownikowej o znaczeniu przymiotnikowym pojawia się jeszcze tylko w Iz 30,9 (w wyrażeniu: בנים כחשים). W 4Q225 termin vxk użyty w wyrażeniu pozytywnym jako orzecznik przybiera znaczenie „słaby”, „niepewny”, „nietrwały”. ${ }^{35} \mathrm{Na}$ takie rozumienie wskazuje fakt, że jest on przeciwstawiony - użytemu w wyrażeniu negatywnym - słowu נאמן (ptc. nifal), które w nifal oznacza „być trwałym”, „być pewnym”, „być wiernym”. Mając na uwadze treść poprzedzającej linii 7, można wnioskować, że aniołowie wrogości cieszą się ze śmierci Izaaka, ponieważ przypuszczają, że okaże on swoją słabość i niepewność, a nie moc i trwałość. Jeśli taki sposób rozumienia tekstu w kol. 2, liniach 7-8 jest słuszny, to można stwierdzić, że dla autora 4Q225 celem parafrazy opowiadania biblijnego z Rdz 22 było podkreślenie prawdy, iż próbie został poddany nie tylko Abraham, ale również jego syn, Izaak. O słuszności takiej sugestii może świadczyć fakt, że podobny motyw pojawia się również w Księdze Judyty, gdzie o działaniu Boga względem Abrahama i Izaaka mówi

34 Zob. G.J. B ro o k e, Further Thoughts on Isaac in the Scrolls from the Qumran Caves, s. 386.

35 Zob. D.J.A. C 1 in e s (red.), The Dictionary of Classical Hebrew, t. IV, Sheffield 1998, s. 383. 
się w następujący sposób: „Przypomnijcie, co uczynił z Abrahamem, i jak poddał próbie Izaaka" (Jdt 8,26). ${ }^{36}$

Warto zwrócić uwagę na fakt, że podczas gdy opowiadanie biblijne kończy się błogosławieństwem Abrahama i obietnicą licznego potomstwa (Rdz 22,17-18), to parafraza w 4Q225 kończy się wzmianką o błogosławieństwie dla Izaaka: „I Bóg, JHWH, błogosławił Iza[aka...]" (kol. 2, linia 10). W ten sposób autor 4Q225 kolejny raz podkreśla rolę Izaaka $\mathrm{w}$ tym wydarzeniu, a tym samym czyni $\mathrm{z}$ niego postać pierwszoplanową i rzeczywistego bohatera całego opowiadania.

\section{Patriarcha Jakub}

W niebiblijnych zwojach qumrańskich - zarówno hebrajskich, jak i aramejskich - wzmianki o patriarsze Jakubie pojawiają się stosunkowo często, gdyż jego imię występuje 92 razy (w różnych formach: יעקוב, יעקב (יעב Jednak w wielu przypadkach wzmianki o Jakubie odnoszą się jego synów (np. CD 3,4; 4Q372 frag. 1, linia 13), lub też do narodu jako całości (np. 4Q175 linie 12 i 17). Jedynie w kilku dokumentach z Qumran znajdują się odniesienia do postaci patriarchy Jakuba oraz wydarzeń z jego życia znanych z Księgi Rodzaju (m.in. 4Q158 frag. 1-2, linie 1-11; 4Q537 frag. 1+2+3; frag. 12; fragmenty Księgi Jubileuszów: 1Q17; 1Q18; 4Q221 frag. 4; frag. 5-6; 4Q222 frag. 1; 4Q223-224), z których na uwagę zasługuje 4Q158. ${ }^{38}$

${ }^{36}$ Zob. F. G a r cía Martín e z, The Sacrifice of Isaac in 4Q225, s. 55; zob. też G. Ve r m e s, New Light on the Sacrifice of Isaac from 4Q225, JJS 47/1996, s. 142.

37 Zob. M.G. A begg i in. (red.), The Dead Sea Scrolls Concordance, t. I (w tekstach hebrajskich: 82 razy, cz. I, s. 315; w tekstach aramejskich: 10 razy, cz. II, s. 847).

38 Zob. R. G o o d, Jacob, w: L.H. S c h if f m a n, J.C. V a n d e r K a m (red.), Encyclopedia of the Dead Sea Scrolls, t. I, s. 395. 
Przeredagowany Pięcioksiąg (4Q158) ${ }^{39}$

Jest on datowany na koniec I w. przed Chr., zachował się w postaci piętnastu fragmentów zawierających odniesienia do Rdz 32, Wj (3-4, 19-24 i 30) oraz Pwt (5 i 18). W frag. 1-2 zachował się opis walki Jakuba z tajemniczym mężem, który po zakończeniu zmagań udzielił mu swego błogosławieństwa (zob. Rdz 32,25-33).

4Q158 frag. 1-2, linie 1-11:

1

2

4

$7 \quad$ [i pobło]gosławił go tam, i powiedział do niego: Niech uczyni cię płodnym JH[WH, i niech uczyni] cię [licznym...]

8

9 aż do tego dnia i aż do pokoleń wieczności [...]

10 I wyruszył w swoją drogę, gdy pobłogosławił go tam, i [...]

11

,aby $[\ldots]$

$[\ldots]$

[... i po]zos[tał J]ak[ub s]am tam, i walczył [...]

[...] gdy walczył z nim, i pochwycił go, i powiedział do nie [go...]

[...] mi. I powiedział do niego: Jakie jest twoje imię? I [powiedział $] \mathrm{mu}[. .$.

[i] z ludźmi, i zwyciężyłeś. I zapytał J[a]kub i powiedz[iał: Pow]iedz mi, ja[kie jest...] słońce, gdy przechodził przez Penue[1...]"

Chociaż tekst qumrański zachował się w stanie bardzo fragmentarycznym, to można zauważyć, że zawiera on przepracowany tekst

39 Wydanie tekstu: J.M. A 11 e g r o, 158. Biblical paraphrase: Genesis, Exodus, w: J.M. A 11 e gro, A.A. A n d e r s on (red.), Qumran Cave 4.I (4Q158-4Q186) (DJD 5), Oxford 1968, s. 1-6 (+ pl. I); zob. też J. S t r u g n e 11, Notes en marge $d u$ volume V des 'Discoveries in the Judaean Desert of Jordan', RQ 7/1970, s. 168-175; M.M. Z a h n, Rethinking Rewritten Scripture: Composition and Exegesis in the 4QReworked Pentateuch Manuscripts, STDJ 95, Leiden-Boston 2011, s. 246-247. 
Rdz 32,25-33, w którym materiał biblijny został poszerzony o kilka elementów..$^{40} \mathrm{~W}$ linii 3 zostało dodane słowo שמה (,tam”, Rdz 32,25), w linii 4 pojawia się dodatkowe wyrażenie ,,i pochwycił go” (por. Rdz 32,26), zaś w linii 6 zwrot לי מה (,mi, ja[kie jest...]”, por. Rdz 32,30).

Największy, a zarazem najbardziej znaczący dodatek pojawia w liniach 7-9. W Księdze Rodzaju stwierdza się jedynie, że tajemniczy „mąż” ( איש), z którym walczył Jakub, pobłogosławił go: „I zapytał Jakub i powiedział: Powiedz, proszę, jakie jest twoje imię? A on powiedział: Czemu pytasz o moje imię? I pobłogosławił go tam [ייברך אתו שם]" (Rdz 32,30). Natomiast autor 4Q158 poszerza tekst biblijny, dodając treść tego błogosławieństwa. Dwa pierwsze jego elementy, które dotyczą płodności i licznego potomstwa są typowe (np. Rdz 1,28; 9,1.7; zob. też Rdz 47,27; Ez 36,11). Wyrażenie (,wiedza i zrozumienie”, linia 8) nie występuje w tekście Rdz 32,25-33, ani w całej Biblii Hebrajskiej (por. דעת ותבונה w Prz 2,6), ale kilkakrotnie pojawia się w zwojach z Qumran (zob. 4Q405 frag. 17, linia 3; 4Q444 frag. 1, kol. 1, linia 3; 4Q426 frag. 1, kol. 1, linia 4; 11Q17 frag. 8, linia 2). Gdy chodzi o wyrażenie „, niech uratuje cię od każdej przemocy [ חמס]" (linia 8), to najbliższą paralelą są słowa w Ps 18,49: ,od człowieka przemocy [ מאיש חמם] uratujesz mnie” (por. 2Sm 22,49). Dodatek zawierający treść błogosławieństwa świadczy o tym, że autor 4Q158 nie potraktował biblijnego wyrażenia ,i pobłogosławił go" (Rdz 32,30) jako standardowej formuły, ale uważał za ważne zamieszczenie treści błogosławieństwa.

\section{$* * *$}

Popularność, jaką cieszyła się Księga Rodzaju wśród członków wspólnoty z Qumran (28 lub więcej kopii), miała wpływ na powstanie bardzo dużej liczby utworów inspirowanych jej treścią i będących parafrazą materiału biblijnego. W zwojach odnalezionych na $\mathrm{Pu}-$ styni Judzkiej interpretujących Rdz 12-50 pojawia się stosunkowo

40 Zob. tamże, s. 27-28; S.W. C r a w ford, Genesis in the Dead Sea Scrolls, s. 355; D.K. F a 1 k, The Parabiblical Texts, s. 116. 
dużo odniesień i aluzji do patriarchów. Niestety, większość tekstów oprócz Apokryfu Księgi Rodzaju (1QapGen) - zachowało się w stanie bardzo fragmentarycznym. $\mathrm{Z}$ jednej strony autorzy dokumentów qumrańskich, wykorzystując materiał biblijny, często wzbogacali go nowymi elementami, a z drugiej pojawiają się one w klasycznej sekwencji wymieniającej ich imiona w kontekście przymierza i obietnic Bożych, oraz są ukazywani jako wzór posłuszeństwa i wierności Bogu.

ks. Marek PARCHEM

Słowa kluczowe: Księga Rodzaju 12-50, patriarchowie Izraela, Qumran

Keywords: The Book of Genesis 12-50, patriarchs of Israel, Qumran

\section{The Book of Genesis 12-50 in Qumran: The Interpretation of the Stories of the Patriarchs in the Selected Texts from the Dead Sea Scrolls}

Summary

The popularity that the Book of Genesis enjoyed among the members of the Qumran community (28 or more copies) undoubtedly accounted for the great number of the works inspired by its content that functioned as the paraphrase of the biblical material. Hence, in the scrolls interpreting the narrative of Gen 12-50 there were found in the Dead Sea Scrolls there are relatively many references and allusions to the patriarchs Abraham, Isaac and Jacob. Unfortunately, most of the texts - apart from the Genesis Apocryphon (1QapGen) - survived in a very fragmentary state only, therefore their interpretation meets serious difficulties and any conclusions should be drawn with the extreme cautiousness. Nevertheless, it can be acknowledged that, in many cases, the authors of the Qumran texts paraphrasing Gen $12-50$, on the one hand enriched the biblical material with new elements by extending and supplementing it and, on the other hand, as in the biblical narratives of Gen, portray the patriarchs in a standard sequence listing their names (i.e. Abraham - Isaac - Jacob) in the context of the covenant and of the divine promises, and present them as the models of obedience, loyalty and faithfulness to God. 